\title{
EFFECT OF SUPERVISION AND QUALITY OF SERVICE ON EMPLOYEE WORK PRODUCTIVITY AT THE HARBORMASTER AND PORT AUTHORITY OFFICE CLASS III KIJANG
}

\author{
Abd. Rachman ${ }^{1}$, Inggerit Paradila Putri ${ }^{2}$, Indrayani ${ }^{3}$, Ngaliman $^{4}$ \\ 1,2,3,4 Faculty of Economics, Department of Management, University of Batam \\ E-mail: ${ }^{1)} \underline{1248 m a n @ g m a i l . c o m ~}$
}

\begin{abstract}
This study is intended to analyze the work productivity of employees at the Harbormaster and Port Authority Office Class III Kijang. By using the variables of supervision and service quality to analyze the effect on the employee's work productivity. The population in this study were employees at the Harbormaster and Port Authority Office Class III Kijang. The samples taken in this study were 30 respondents. Data collection was used by the questionnaire method, namely by providing a list of questions to the respondents. The results of this study indicate that supervision and service quality affect the work productivity of employees at the Harbormaster and Port Authority Office Class III Kijang where the $\mathrm{R}$ value is $0,683(68.3 \%)$. While the $\mathrm{R}$-square coefficient $=0.467$ so that the coefficient of determination $(\mathrm{R} 2)=46.7 \%$ can be calculated. For the partial test ( $\mathrm{t}$ test) it was found that the supervision was accepted, with a significant value of $0.035<0.05$, the quality of service was accepted, so that a significant value of $0.000<0.05$ was obtained. While the simultaneous test is obtained Fcount $>$ Ftable or 11.807 > 3.34 and Fsig level $0.000<0.05$ then Ha accepted.
\end{abstract}

Keywords: Supervision, Service Quality, Work Productivity

\section{INTRODUCTION}

The Port of Kijang is a port that is open and used for national and international trade and is the gateway to the economy in the western region of Indonesia, and its operation is carried out by the central government in this case by the Harbormaster and Port Authority Office Class III Kijang. Seeing the above, the Harbormaster and Port Authority Office Class III Kijang in port management activities really need supervision. This supervision is carried out as an effort to determine whether the activities are carried out in accordance with the established plan. This also means that supervision is an action or activity that seeks to ensure that the work is carried out properly and in accordance with the applicable regulatory procedures.

Supervision is very important in every job. Because with good supervision, a job will be able to run smoothly and can produce an optimal work result. The smoother the work and accompanied by good supervision, the work will be successful. With good supervision at the Harbormaster and Port Authority Office Class III Kijang, it will encourage employees to be more active in work and produce good work completion and productivity. 
In improving port management activities at Kijang Harbor, it is very necessary to have professional, capable and reliable human resources. In this study, the population sample will be the employees of the Harbormaster and Port Authority Office Class III Kijang, totaling 30 respondents. Table 1 below describes in detail the sample population of the Harbormaster and Port Authority Office Class III Kijang employees :

Table 1

Population of Harbormaster and Port Authority Office Class III Kijang Employees

\begin{tabular}{|c|c|rl|}
\hline No & Section / Division & Number of Employees \\
\hline 1. & Sub Division of Administration & 8 & Person \\
\hline 2. & $\begin{array}{c}\text { Section of Traffic and Sea } \\
\text { Transportation and Port Business }\end{array}$ & Person \\
\hline 3. & $\begin{array}{c}\text { Section of Sailing Safety, Guard } \\
\text { and Patrol }\end{array}$ & 10 & Person \\
\hline 4. & Section of Legal Status of Ship & 6 & Person \\
\hline \multicolumn{2}{r|}{ Total Population } & 30 & Person \\
\hline
\end{tabular}

Source: Primary Data Processed, Year 2021

According to Schermerhorn (in Sule and Kurniawan, 2005:317), Supervision is a process in determining performance measures and taking actions that can support the achievement of the expected results in accordance with the predetermined performance. According to Bangun (2008:164), Supervision is a process to assess the suitability of the work of members of the organization in various fields and various levels of management with a predetermined program.

Besides supervision, service quality also plays a very important role in increasing work productivity. Because if the quality and quality of services provided to users of shipping services is very good, then the results of port operations will run smoothly and productivity will run as planned.

This is in accordance with what Inggerit Paradila Putri said, that improving the quality of services related to the needs and expectations of the community is the most important part in improving the quality of service quality so that the work productivity of the agency can develop and can maintain its business.

According to Hardiansyah (2018: 49) service quality is a dynamic condition related to products, services, people, processes and the environment that meet or exceed expectations. In an agency, it is very necessary to have work productivity to achieve the goals that have been set. Work productivity is a result of the work requirements that must be met by employees to obtain maximum results where in practice, work productivity lies in the human factor as the executor of work activities.

Work productivity is often defined as the ability of a person or group of people to produce goods or services. The main objective of increasing employee productivity is so that employees at both the lower and upper levels are able to become efficient, effective and productive employees. A productive employee is an employee who is agile and able to produce goods or services according 
to the specified quality and in a shorter time, so that in the end a high level of employee productivity can be achieved. Thus it is important for a leader to try to increase employee productivity, so that the agency can develop and be able to maintain its business.

\section{IMPLEMENTATION METHOD}

The research method is basically a scientific way to get data with certain goals and uses (Sugiyono, 2016: 2). This research method uses quantitative methods, because the research data is in the form of numbers and the analysis uses statistics (Sugiyono, 2018: 8). In this study, the sample technique was used using the Slovin formula and $10 \%$ precision was taken, so the sample in this study was 30 respondents.

The type of data used is primary data. Primary data is the main type of data that supports research, this primary data source is obtained directly from respondents (Rumengan et al, 2020: 150-151). Research through respondents' answers in the research questionnaire given.

To collect data, data were collected directly using the field research method, namely in the form of distributing questionnaires to employees. In this study, the measurement of data is a questionnaire list of questions arranged based on a grid in the form of a Likert scale (five-level scale) (Ghozali, 2016:47).

Perform hypothesis testing using multiple linear regression analysis (Y), individual parameter significant test ( $\mathrm{t}$ statistical test), simultaneous significant test (F statistical test), and the coefficient of determination test (R2).

\section{RESULTS AND DISCUSSION}

\section{Structural Model Design (Inner Model)}

This study uses 2 (two) variables, namely the Independent Variable (Free) namely Supervision (X1) and Service Quality (X2). And the Dependent Variable (Bound) namely Work Productivity (Y).

According to Sekaran and Bougie (2017), a hypothesis can be defined as a tentative, but testable, statement that predicts what you want to find in empirical data. From the description above, it can be concluded that the hypothesis or provisional conjecture is as follows:

$\mathrm{H} 1$ : It is suspected that there is a positive and significant effect of supervision on employee work productivity.

$\mathrm{H} 2$ : It is suspected that there is a positive and significant effect of service quality on employee work productivity.

H3 : It is suspected that together there is a positive and significant influence of supervision and service quality on employee work productivity. 


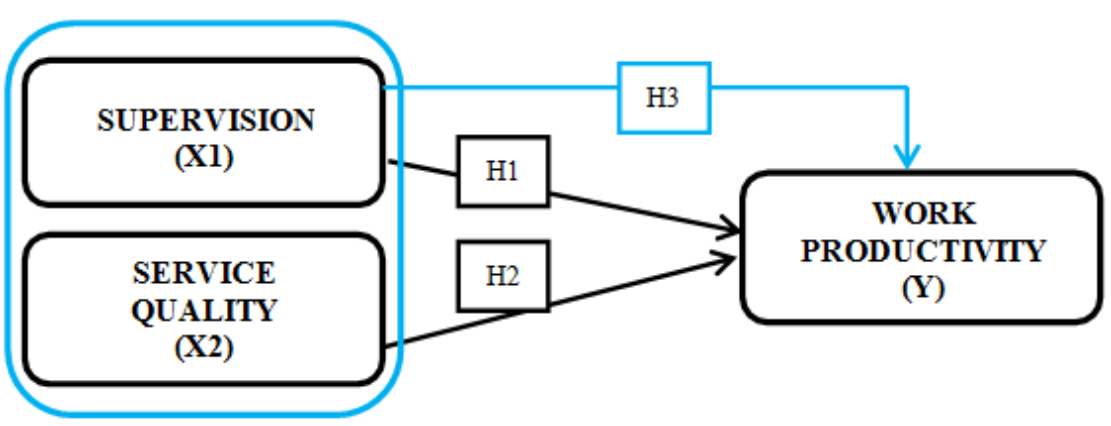

Figure 1 Research Framework and Research Hypotheses

2. Research Construct Measurement Model (Outer model)

a) Multiple Linear Regression Equation Analysis (Y)

According to Pardede and Manurung (2014: 27), that in multiple regression, the dependent variable is influenced by two or more independent variables so that there is a functional relationship between the dependent variable (Y) namely Work Productivity, with independent variables namely: Supervision (X1) and Service Quality (X2). The results of the analysis of multiple linear regression equations from a sample of 30 respondents are shown in Table 2 as follows :

Table 2

Multiple Linear Regression Test Results

\begin{tabular}{|c|c|c|c|c|c|c|}
\hline \multicolumn{7}{|c|}{ Coefficientsa } \\
\hline \multirow{2}{*}{\multicolumn{2}{|c|}{ Model }} & \multicolumn{2}{|c|}{$\begin{array}{l}\text { Unstandardized } \\
\text { Coefficients }\end{array}$} & $\begin{array}{c}\text { Standardized } \\
\text { Coefficients }\end{array}$ & \multirow[b]{2}{*}{$\mathrm{t}$} & \multirow{3}{*}{$\begin{array}{c}\text { Sig. } \\
.095\end{array}$} \\
\hline & & B & Std. Error & Beta & & \\
\hline \multirow[t]{3}{*}{1} & (Constant) & 13,751 & 7,954 & & 1,729 & \\
\hline & SUPERVISION (X1) & 0.060 & ,206 & .043 & ,289 & 0.035 \\
\hline & QUALITY OF SERVICE (X2) & ,880 & , 196 & ,668 & 4,498 &, 000 \\
\hline
\end{tabular}

Source: Primary Data Processed, Year 2021

Based on data analysis using SPSS 24 , the results of the regression equation are as follows :

$$
\mathrm{Y}=13,751+0.060 \mathrm{X} 1+0.880 \mathrm{X} 2+\mathrm{e}
$$

The constant value is 13,751 which means that there is no change in the variables of supervision and service quality (value X1 and X2 is 0 ) then the employee's work productivity There are 13,751 units of Harbormaster and Port Authority Office Class III Kijang.

b) Individual Parameter Significant Test (Test Statistical t)

According to Pardede and Manurung (2014:29), the value of Tcount used to partially test the effect of supervision (X1) and service quality (X2) on the dependent variable of Work Productivity (Y) or not with an error rate of $5 \%$ by looking at the significance column of each independent variable (free) with a significant level $<0.05$. It can be seen in Table 3 below : 
Table 3

T Test Results (Partial)

\begin{tabular}{|c|c|c|c|c|c|c|}
\hline \multicolumn{7}{|c|}{ Coefficientsa } \\
\hline \multirow{2}{*}{\multicolumn{2}{|c|}{ Model }} & \multicolumn{2}{|c|}{$\begin{array}{c}\text { Unstandardized } \\
\text { Coefficients }\end{array}$} & \multirow{2}{*}{$\begin{array}{c}\text { Standardized } \\
\text { Coefficients }\end{array}$} & \multirow[b]{2}{*}{$\mathrm{t}$} & \multirow[b]{2}{*}{ Sig. } \\
\hline & & $\mathrm{B}$ & Std. Error & & & \\
\hline \multirow[t]{3}{*}{1} & (Constant) & 13,751 & 7,954 & & 1,729 & ,095 \\
\hline & SUPERVISION (X1) & 0.060 & ,206 & .043 & 289 & 0.035 \\
\hline & QUALITY OF SERVICE (X2) &, 880 & ,196 & ,668 & 4,498 & ,000 \\
\hline & a. $\mathrm{D}$ & ble & RK PRO & TIVITY (Y) & & \\
\hline
\end{tabular}

Source: Primary Data Processed, Year 2021

- Supervision Variable (X1) has a positive and significant effect on Work Productivity employee Harbormaster and Port Authority Office Class III Kijang. It can be seen that H1 is accepted with a significant value of Supervision (X1) $0.035<0.05$. means Ha is accepted and $\mathrm{H} 0$ is rejected.

- Service Quality Variable (X2) has a positive and significant effect on Work Productivity employee Harbormaster and Port Authority Office Class III Kijang. It can be seen that $\mathrm{H} 2$ is accepted with a significant value of Service Quality (X2) $0.000<0.05$. means $\mathrm{Ha}$ is accepted and $\mathrm{H} 0$ is rejected.

c) Test Simultaneous Significance (Statistical Test F)

According to Pardede and Manurung (2014: 28), the F test can be used to simultaneously test the effect of the independent variable on the dependent variable (Y). If the value of Fcount > Ftable then it can be interpreted that the regression model is correct, meaning that it influences together, by looking at the value of Ftable $=(\mathrm{k} ; \mathrm{n}-\mathrm{k}), \mathrm{F}=(2 ; 30-2)$, Ftable $=(2 ; 28)=3.34$ with an error rate of $5 \%$. The $\mathrm{F}$ test performed can be seen in Table 4 below :

Table 4

\section{F . Test Results}

\begin{tabular}{|l|l|r|r|r|r|r|}
\hline \multicolumn{7}{|l|}{ ANOVAa } \\
\hline \multicolumn{2}{|l|}{ Model } & Sum of Squares & Df & Mean Square & F & Sig. \\
\hline 1 & Regression & 1236,053 & 2 & 618,026 & 11,807 &, $000 \mathrm{~b}$ \\
\cline { 2 - 7 } & Residual & 1413,314 & 27 & 52,345 & & \\
\cline { 2 - 7 } & Total & 2649,367 & 29 & & & \\
\hline
\end{tabular}

Source: Primary Data Processed, Year 2021

It can be seen in the table above that Fcount is 11.807 with Ftable value is 3.34 so that Fcount > Ftable or $11.807>3.34$ and Fsig level $0.000<0.05$ then H0 rejected and Ha accepted. Can be concluded that Supervision variables (X1) and Service Quality (X2) simultaneously have a 
significant effect on the Work Productivity of the Harbormaster and Port Authority Office Class III Kijang employees.

d) Test Coefficient of Determination ( R2 )

The value of the coefficient of determination is zero and one. Score R2 low : the ability of the independent variables in explaining the variation of the dependent variable is very limited. Score R2 which is close to one : the independent variables provide almost all the information to predict the variation of the dependent variable. It can be seen in Table 5 below :

Table 5

Coefficient of Determination Test Results

\begin{tabular}{|c|c|c|c|}
\hline \multicolumn{4}{|c|}{ Model Summary } \\
\hline & & & Std. Error of theEstimate \\
\hline $\mathrm{R}$ & R Square & Adjusted R Square & \\
\hline ,683a & ,467 & ,427 & 7,235 \\
\hline
\end{tabular}

Source: Primary Data Processed, Year 2021

The coefficient of determination is found in the Adjusted R Square value of 0.427. It means that the ability of the independent variable in explaining the dependent variable is $42.7 \%$, the remaining $57.3 \%$. explained by variables not examined in this study.

\section{DISCUSSION}

The results of the study have implications for proving that supervision greatly affects the work productivity of employees at the Harbormaster and Port Authority Office Class III Kijang. Service quality is also a determining factor for work productivity, because service quality is the most important part in improving quality so that work productivity can be achieved.

In further research, it is necessary to add other independent variables, such as the need for skilled employees in mastering science and technology (IPTEK) and formal and informal education. Because we can only master each technology with reliable knowledge, skills and abilities, so that we can produce new research that can assist organizations in increasing employee productivity, especially at the Harbormaster and Port Authority Office Class III Kijang.

\section{CONCLUSION}

Based on the results of this study, it can be concluded that:

1. There is a positive and significant effect of supervision on employee work productivity.

2. There is a positive and significant effect of service quality on employee work productivity.

3. Taken together, there is a positive and significant effect of supervision and service quality on employee productivity.

\section{REFERENCES}

Sule, and Ernie Tisnawati, Kurniawan Saefullah. 2005. Introduction to Management. Jakarta : Pranada Media Group.

Wake up Wilson. 2008. Digest Management. Jakarta : Refika Aditama. 
Hardiyansyah. 2018. Quality of Public Service. Yogyakarta : Gava Media.

Ilham, R. N., Sinaga, S., Putri, D. E., Sinta, I., \& Fuadi, F. (2021). EFEK DARI LEVERAGE DAN UKURAN PERUSAHAAN DALAM MEMENGARUHI TINGKAT PROFITABILITAS. JURNAL ILMIAH EDUNOMIKA, 5(02).

Khaddafi, M., Subrata, H., Apriyanto, E., Iqbal, M., \& Darmawan, W. (2022). PENGENALAN DASAR PENGOPERASIAN KOMPUTER PADA ANAK USIA DINI. JATIMIKA: Jurnal Kreativitas Mahasiswa Informatika, 2(3).

Sugiyono. 2016. Quantitative, Qualitative and R\&D Research Methods. Bandung : Alphabeta.

Rumengan, Jemmy et al. 2020. Research Methods. Aceh : CV. Sefa Bumi Persada.

Ghozali, Imam. 2016. Application of Multivariate Analysis with IBM SPSS 25 Program Edition 9. Semarang: Publishing Agency - Undip..

Pardede, R., \& Manurung, R. (2014). Path Analysis / Path Analysis Theory and Applications in Business Research (first). Jakarta : PT. Rineka Cipta.

Putri, D. E., Ilham, R. N., \& Syahputri, A. (2021). Efek mediasi profitabilitas pada pengaruh leverage dan ukuran perusahaan terhadap nilai perusahaan. Jurnal Ilmiah Edunomika, $5(02)$. 
EFFECT OF SUPERVISION AND QUALITY OF SERVICE ON EMPLOYEE WORK PRODUCTIVITY AT THE HARBORMASTER AND PORT AUTHORITY OFFICE CLASS III KIJANG

DOI: https://doi.org/10.54443/ijerlas.v2i1.143 